new scientific session to our meeting. What followed was a series of informal, spirited talks on topics ranging from viral hepatitis to developmental cardiac anomalies, skeletal muscular dystrophies, and cancer therapeutics. This exercise sparked our recognition of the diversity of talent among us as well as the remarkable scientific overlap in our respective fields. As just one example, the signal transduction pathway abnormalities associated with cardiac outflow tract defects are similarly involved in cancer initiation and progression. Not only do many of us study the same sets of genes, we assemble complementary sets of scientific reagents that can enhance each other's work. You can imagine the dinner conversations that followed.

Yes, the Atlantic City days are over, and specialty meetings will continue to be the venue for reporting late-breaking discoveries. But I am convinced that the ASCI remains an important venue for scientific exchange and for insuring that the lessons we learn in career development, mentoring, and juggling administrative duties are communicated to subsequent generations. Just as Samuel Meltzer instructed the first Young Turks in 1908, we continue to listen to our senior ASCI colleagues - for example, to the sug- gestion by Lefkowitz (3) that we add short presentations of latebreaking science and to Kelley's recommendation (4) that we pass along our collective wisdom (to our junior colleagues in the American Physician Scientists Association [APSA] who now join us each year). Last, we all share the unique responsibility of ensuring that our discoveries have an impact in medical practice. In this greatest of all challenges, we will always remain relevant, united, and the closest of colleagues.

Address correspondence to: Charles L. Sawyers, Howard Hughes Medical Institute and Memorial Sloan-Kettering Cancer Center, 1275 York Avenue, New York, New York, USA 10021. Phone: (646) 888-2138; Fax: (646) 888-2595; E-mail: sawyersc@mskcc.org.

1. Brainard, E.R. 1959. History of the American Society for Clinical Investigation, 1909-1959. J. Clin. Invest. 38:1784-1864.

2. Weber, B.L. 2007. In the palace of the sultan: 2007 American Society for Clinical Investigation Presidential Address. J. Clin. Invest. 117:1727-1731.

3. Lefkowitz, R.J. 2008. The annual ASCI meeting: does nostalgia have a future? J. Clin. Invest. 118:1231-1233.

4. Kelley, W.N. 2008. ASCI: reflections on the first 100 years and a proposal for the next. J. Clin. Invest. 118:1217-1219.

\title{
The ASCl, the spring meetings, and growing up in academic medicine: a personal perspective
}

\author{
Anthony S. Fauci \\ National Institute of Allergy and Infectious Diseases, NIH, Bethesda, Maryland, USA.
}



For many young physician-scientists, the American Society for Clinical Investigation spring meetings are the backdrop to their initiation into academic medicine. Membership in the ASCI is a high honor and represents one's maturation and accomplishment in clinical research. The ASCI continues to provide this meeting forum for young investigators who aspire to emulate their idols and mentors just as I did in 1969 when I attended the spring meetings in Atlantic City for the first time.

It seems both like yesterday and forever ago that in spring 1969 scores of my fellow clinical associates and I, MDs from across the country who were taking clinical research fellowships at the NIH immediately following residencies in internal medicine, piled into our cars and headed north. We left Bethesda, Maryland, drove around the Beltway and up Route 95 to Atlantic City for our first experience at the "clinical meetings." We went because we were told that we had to go by our bosses (Sheldon Wolff, in my case), since it was at the ritual of the annual spring meetings where academic medicine and clinical research showed its stuff. The same scene was repeated at virtually every academic medical center throughout the country. Young, aspiring physician-scientists came to see, hear, and learn from the masters, the very individuals whose papers they had read and quoted on rounds during their house staff training. None of us from the NIH group had been in the laboratory long enough to have accumulated enough data to present; most were still in the clinical year of a three-year fellowship and

Conflict of interest: The author has declared that no conflict of interest exists. Citation for this article: J. Clin. Invest. 118:1214-1217 (2008). doi:10.1172/JCI34724. had not even entered the laboratory. Nonetheless, this trip marked the beginning of an extraordinary journey in which the American Society for Clinical Investigation and its annual spring meetings, usually held jointly with the Association of American Physicians (AAP) and the American Federation for Clinical Research (AFCR), became the backdrop to our initiation and ultimate maturation in academic medicine. There are so many aspects of the uniqueness and importance of the ASCI and its annual meeting that come to mind; I would like to briefly recall some of them.

\section{The ASCl: the gold standard of excellence}

It became clear to me as I progressed over the years through my fellowship, and as I began assuming independence as a basic and clinical investigator, that the ASCI represented the gold standard of excellence in medical research. There was no question that you submitted and hopefully presented your very best work to the assembled ASCI members at the annual meetings; if you were lucky, you might even get to present at a plenary session. One of the most exciting moments in my early career was presenting a paper in 1973 at the AFCR plenary session on my year-long work 


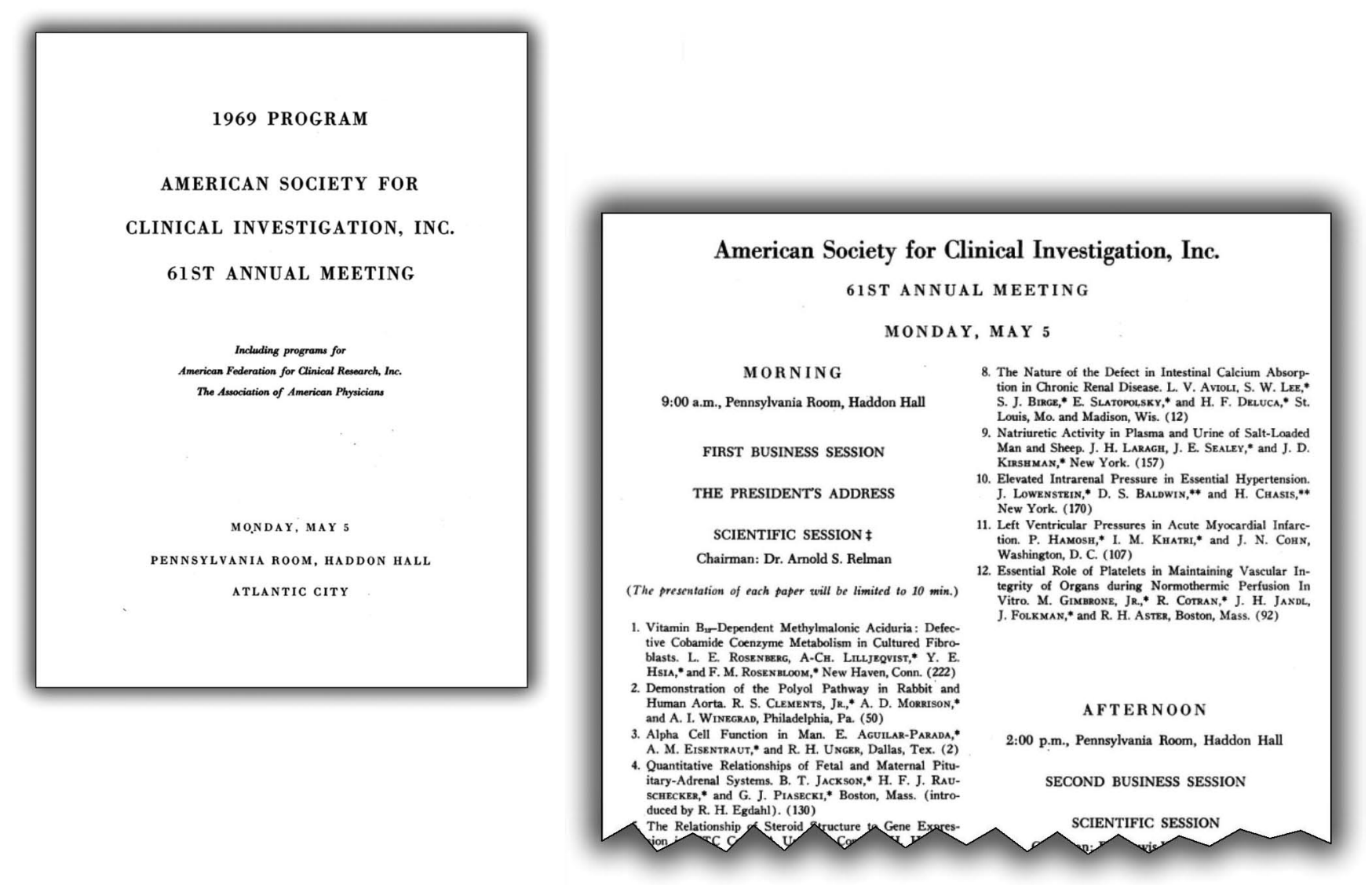

Figure 1

First page of the official program for the annual meeting of the ASCI held in Atlantic City on May 3-6, 1969.

describing "The effect of in vivo hydrocortisone on in vitro lymphocyte function in humans" (1). The audience was filled with a significant portion of the ASCI and AAP membership, people who had been my idols and role models throughout medical school and house staff training. Despite more than three decades of presenting lectures at venues throughout the world, I still get a thrill reflecting on that spring morning in Atlantic City when I showed my stuff for the first time to my academic heroes. When the intimidating Henry Kunkel of Rockefeller University came to the microphone and asked a question (that I answered correctly, so he later told me), I was on top of the world. I believe strongly that we need standards of excellence in all walks of life, and the conduct of biomedical research is no exception. In many ways, the ASCI provides this standard for our field. Society membership symbolizes deserved recognition and inclusion in the ranks of those whose accomplishments we respect and whose performance we emulate.

\section{Being in the audience}

That all the giants of academic medicine were members of the ASCI only contributed to its storied and distinguished history. In addition, it was a given that the best clinical research would be presented for the first time at the Society's annual meetings. Almost as exciting as presenting a paper was the thrill we felt sitting in the audience and witnessing for the first time the presentation by ASCI members or soon-to-be members of what would surely become classics of biomedical research. This led to a feel- ing that you were participating in the evolution of your profession. As an audience participant, you could take a vicarious thrill in what was happening all around you. As an example of this phenomenon, I have retrieved from the ASCI archives the program from the very first ASCI meeting that I attended on May 3-6, 1969, in Atlantic City (Figure 1). In that program from more than 38 years ago, not even taking into account the presentations that were made during the AAP and AFCR components of the same meeting, one gets a feeling for the significance and impact of the material that was presented that weekend (Table 1). Indeed, a part of medical history was being written. Perusal of the programs of subsequent years yielded a similarly impressive array of medical breakthroughs that were first presented in public at the ASCI annual meetings.

Yet at these same ASCI meetings four years later, I was exposed (without realizing it at the time) to the darker side of biomedical research as I listened intently on April 30, 1973, in the Pennsylvania Room of Haddon Hall to what was felt at the time to be one of the most important medical breakthroughs in decades. William Summerlin presented the paper "Successful tissue and organ allotransplantation without immunosuppression." At the end of the presentation, the entire audience rose for a standing ovation. The barriers to transplantation had been removed, so we thought. Unfortunately, it was my first exposure to flagrant fraud in science, as it would later be revealed that Summerlin's data had been completely fabricated (2). 


\section{Table 1}

Selected presentations at the ASCI meeting in Atlantic City on May 3-6, 1969, and their ultimate implications

\begin{tabular}{|c|c|c|}
\hline Title & Senior author(s) & Ultimate implications \\
\hline "Treatment of red cell aplasia with immunosuppressive drugs" & Sanford Krantz & $\begin{array}{l}\text { Early success in the use of immunosuppressive } \\
\text { drugs for marrow hypoplasias }\end{array}$ \\
\hline $\begin{array}{l}\text { "Early diagnosis and treatment of rejection following } \\
\text { cardiac transplantation" }\end{array}$ & Norman Shumway & $\begin{array}{l}\text { Breakthrough in successful treatment of } \\
\text { heart transplant rejection }\end{array}$ \\
\hline $\begin{array}{l}\text { "Localization of parathyroid adenomas by selective } \\
\text { venous catheterization and radioimmunoassay" }\end{array}$ & John Potts & $\begin{array}{l}\text { Critical segue into precise diagnosis and safe } \\
\text { removal of parathyroid adenomas }\end{array}$ \\
\hline "Studies of human amyloid" & \multirow{2}{*}{$\begin{array}{c}\text { Edward Franklin and Dorothea Zucker-Franklin } \\
\text { Robert Levy }\end{array}$} & Classic description of human amyloidosis \\
\hline $\begin{array}{l}\text { "Familial type II hyperlipoproteinemia: a defect } \\
\text { of beta lipoprotein apoprotein catabolism?" }\end{array}$ & & $\begin{array}{l}\text { First description of one of several important } \\
\text { hyperlipoproteinemias }\end{array}$ \\
\hline "Serum $\alpha$-fetoprotein ( $\alpha$-FP) in cancer patients" & Paul Carbone & Breakthrough in diagnosis of certain cancers \\
\hline "Hepatitis virus and Australia antigen" & Baruch Blumberg & $\begin{array}{l}\text { Discovery of hepatitis B; led to } 1976 \text { Nobel Prize } \\
\text { in Physiology or Medicine }\end{array}$ \\
\hline
\end{tabular}

On the public policy front, I got my first taste of the tensions arising from dependence of the academic biomedical research community on government funding as I listened to outgoing ASCI president Arnold S. (Bud) Relman's presidential address to the Society entitled "Academic medicine and the public" (3). In his discussion of medical education, Relman said: "This problem has now been compounded by the recent tightening of NIH funds. Everyone knew that the logarithmic rate of growth in appropriations, which occurred during the decade 1955-1965, could not be sustained, but 3 years ago when increasing military expenditures forced Congress suddenly to apply the brakes, a shock was generated which has continued to shake the foundations of the academic medical establishment ever since." Indeed, what is past is prologue. The resemblance to the situation that we are facing today is unmistakable (4).

\section{Ambiance and collegiality}

It is easy to reminisce about Atlantic City, but this would have little meaning to members who had never attended an ASCI meeting there. There is a spirit that was established in Atlantic City over the decades during which the meetings were held there that still prevails regardless of the physical location of the meetings. The gatherings in the lobby of Haddon Hall, the stately hotel where the major scientific sessions were held (Figure 2); the steamed crabs at Captain Starn's, the legendary restaurant located nearby on the Boardwalk, where there was never an empty seat; the martinis at Zaberer's, the watering hole a few miles outside of Atlantic City; and the walks along the Boardwalk in the early morning and at sunset - all of these provided a milieu of warmth, affection for one's peers and idols, and a feeling of wanting to belong and of gradually coming to belong. My day was made if walking on the

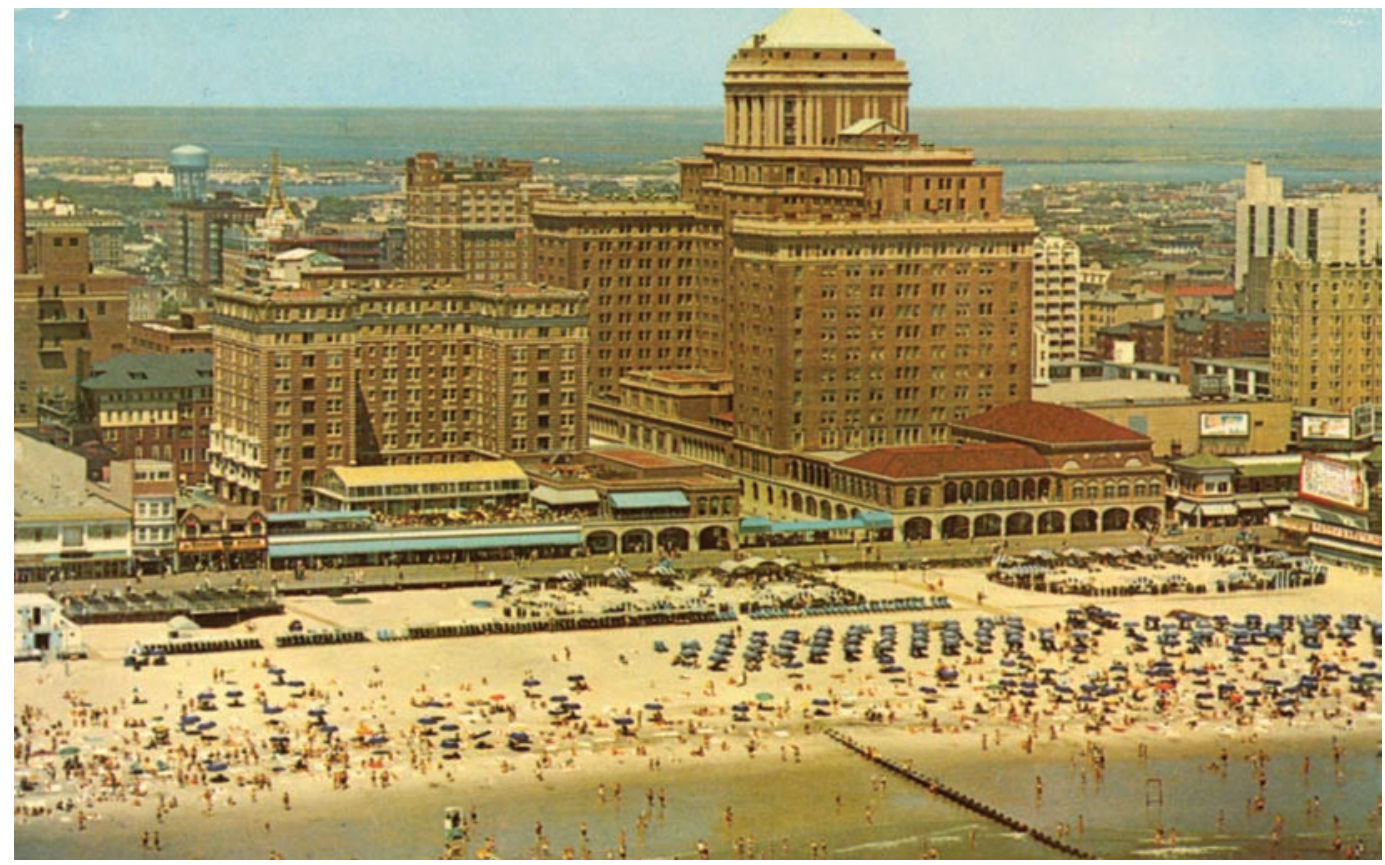

Figure 2

Haddon Hall — the historic Atlantic City, New Jersey, hotel that served as the official meeting place for the ASCI annual meetings. 
Boardwalk or eating in a restaurant I would run into Eugene Braunwald, Kurt Isselbacher, Donald Seldin, Lloyd (Holly) Smith, or James Wyngaarden, among others, and they would stop for a brief moment and congratulate me on a paper I had presented that day. It is part of the fuel that drives us, to be accepted by the people you greatly admire. It was this experience that convinced me in subsequent years and up to this day to greet, shake hands with, and spend a minute or two speaking with the young aspiring physician-scientists who I run into at the spring meetings, be they in Washington, DC, Baltimore, the West Coast, or, as has been the case for the past several years, Chicago.

\section{Membership in ASCI}

There are few thrills in the life of a young physician-scientist more exciting than election to membership in the ASCI. I had attended several successive ASCI meetings following my introduction to the ritual in 1969. I had published a few articles in The Journal of Clinical Investigation. I was still a little starstruck, but now I wanted not only to be accepted by the people who I admired, but to actually be one of them. In the early spring of 1976, after toiling for four years as a young independent investigator, I was elected to membership in the ASCI. I was ecstatic. Yet in an interesting twist, membership in the Society, as opposed to being an end in itself, actually became for me an incentive to perform at an even higher level in order to live up to the tradition established by the many distinguished members who had preceded me. In speaking with several of my peers, they expressed similar reactions to their ASCI elections. We were elected into the club on the basis of merit. Now that we were part of the club, we needed to continue to perform like we belonged there. Although membership in the ASCI is often a requirement for further academic advancement including promotions and resources, I maintain that the internal bar that it sets for us is as important as anything else.

\section{The future of the ASCI}

I believe that the future of the ASCI will be healthy and enduring. The fundamental principles upon which clinical research is based are inherent to the principles of the ASCI: excellence in science, creativity, integrity, and service to the public through clinical research to improve the health of the nation and the world. The future of clinical research can only remain healthy if we continue to train outstanding young men and women who will push the envelope of science and continue to explore the unknown. These individuals will benefit from associating with a tradition of excellence and productivity. I am certain that the ASCI will continue to provide this milieu for them and will serve as an important goal for those young people who aspire to emulate their idols and mentors just as I did when I took that first drive from Bethesda to Atlantic City in the spring of 1969.

Address correspondence to: Anthony S. Fauci, NIAID, NIH, Building 31, Room 7A-03, 9000 Rockville Pike, 31 Center Drive MSC 2520, Bethesda, Maryland, USA. Phone: (301) 496-2263; Fax: (301) 496-4409; E-mail: afauci@niaid.nih.gov.

1. Fauci, A.S., and Dale, D.C. 1974. The effect of in vivo hydrocortisone on subpopulations of human lymphocytes. J. Clin. Invest. 53:240-246.

2. Hixson, J.R. 1976. The patchwork mouse. Anchor Press. New York, New York, USA. 228 pp.

3. Relman, A.S. 1969. Academic medicine and the public. J. Clin. Invest. 48:1169-1171.

4. Zerhouni, E. 2006. NIH in the post-doubling era: realities and strategies. Science. 314:1088-1090.

\title{
ASCl: reflections on the first 100 years and a proposal for the next
}

\author{
William N. Kelley
}

University of Pennsylvania, Philadelphia, Pennsylvania, USA.

\begin{abstract}
ASCI
Congratulations to the ASCI and its membership on the first 100 years. From their first organizational meeting on the Boardwalk in Atlantic City in June 1907, our predecessors recognized the need for an organization for the clinician who had a strong interest in true experimental medicine. These nine Young Turks formed the Society, had their first meeting at the Willard Hotel in Washington, DC, in
went on to become some of the leaders of American medicine in the first half of the 20th century. The 100тн 1909, and went on to become some of the leaders of American medicine in the first half of the 20th century. The
establishment of the JCI in 1924 further enhanced the high standards of the ASCI and its membership. Surely thousands of us have benefited from the foundation of the ASCI and the JCI, as have, I would submit, millions of patients as well.
\end{abstract}

\section{Reflections}

My first serious exposure to research began in the summer of 1965 when I arrived at the NIH as a clinical associate in the National Institute of Arthritis and Metabolic Diseases. I had done some research as a medical student at Emory University, first in a cardiovascular laboratory in the Pharmacology Department under Marion Cotton and later in the General Clinical

Conflict of interest: The author has declared that no conflict of interest exists. Citation for this article: J. Clin. Invest. 118:1217-1219 (2008). doi:10.1172/JCI34652.
Research Center under Garland Herndon. As wonderful as those experiences were, I knew I was in a different league as I walked into Building 10, known then as the Clinical Center, on the NIH campus on July 1, 1965. This massive building is a large hospital encircled by research laboratories sitting in the middle of a large campus, around which there are dozens of other research and administrative buildings. In addition, once inside, I was struck by the pristine, well-attended, and quiet patient care units on each floor surrounded by multiple wings of research space. This was also not the wild and woolly West that I had experienced 